\title{
Role of echocardiography in atrioventricular canal defects assessment
}

\section{Denis Došen*, Željko Baričević, Kristina Marić-Bešić, Darko Anić, Maja Strozzi}

University of Zagreb School of Medicine, University Hospital Centre Zagreb, Zagreb, Croatia

\section{RECEIVED:}

March 11, 2017

ACCEPTED:

April 6, 2017

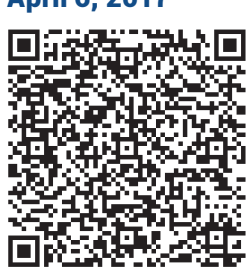

KEYWORDS: atrioventricular canal defects, echocardiography, 3D transesophageal echocardiography. CITATION: Cardiol Croat. 2017;12(4):154-155. | https://doi.org/10.15836/ccar2017.154

*ADDRESS FOR CORRESPONDENCE: Denis Došen, Klinički bolnički centar Zagreb, Kišpatićeva 12, HR-10000 Zagreb, Croatia. / Phone: +385-98-548-540 / E-mail: denisdosen@gmail.com

ORCID: Denis Došen, http://orcid.org/0000-0003-3490-5505 • Željko Baričević, http://orcid.org/0000-0002-5420-2324 Kristina Marić-Bešić, http://orcid.org/0000-0002-4004-7271 • Darko Anić, http://orcid.org/0000-0002-7378-944X Maja Strozzi, http://orcid.org/0000-0003-4596-8261

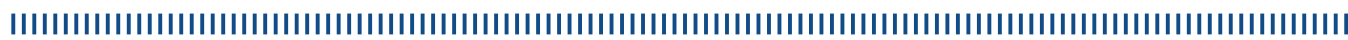

Introduction: Atrioventricular (AV) canal defects are a group of congenital cardiac defects involving the AV septum and AV valves (ie. mitral and tricuspid valves). Combinations of these anatomic abnormalities result in complete (both atrial and ventricular septal defects [ASD/VSD] and partial (only ASD) forms that are manifested in varying clinical presentations. ${ }^{1-4}$

Case 1: 35-year-old patient with Down syndrome and untreated complete AV canal defect who developed Eisenmenger syndrome and has been treated with bosentan (Figure 1).

Complete AV canal defect is a result of complete failure of fusion between the superior and inferior endocardial cushions. It is characterized by a primum ASD that is contiguous with a posterior (or inlet) VSD and a common AV valve.

Case 2: 61-year-old patient with partial AV canal defect who undergone surgical correction 2 years ago and is now in NYHA I class status (Figure 2)

Partial AV canal defect is due to incomplete fusion of the superior and inferior endocardial cushions and consists of a primum ASD and a single AV valve annulus with two separate valve orifices. Due to abnormal fusion of the left tubercle of the superior and inferior cushions, the anterior leaflet of the mitral valve typically is cleft.

Case 3: 26-year-old patient with transitional AV canal defect. Due to 1.5:1 left to right shunt without signs of significant right ventricle volume overload, she will undergo further evaluation in 6 months (Figure 3)

Transitional AV canal defect is anatomically a subtype of complete AV canal defect as it consists of a large primum defect, cleft mitral valve and inlet VSD. However, dense chordal attachments to the ventricular septum lead to small insignificant ventricular shunting and delineation of distinct left and right $\mathrm{AV}$ valve orifices, resulting in a defect that is similar to the physiology of a partial AV canal defect.

Case 4: 48-year-old patient undergone surgical correction 2 months ago due to development of bidirectional shunt (dominantly left to right with Qp/Qs 2.1:1) (Figure 4).

Intermediate AV canal defect is a rare subtype of complete AV canal defect in which a bridging tongue of tissue divides the common AV valve into two distinct orifices. This defect is similar to a complete

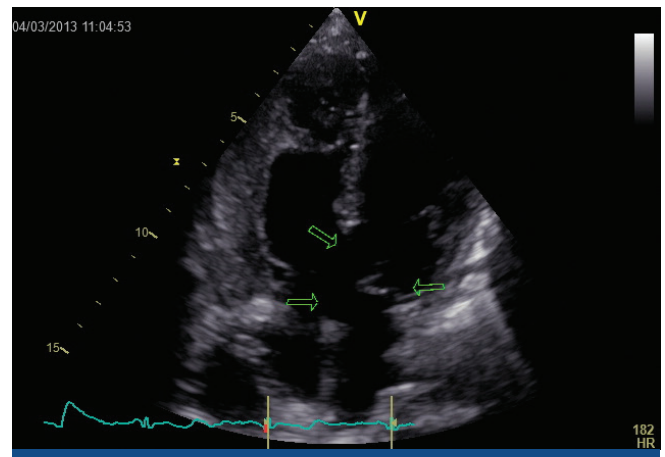

FIGURE 1. 4 chamber view - arrows pointing towards primum atrial septal defect, inlet ventricular septal defects and a common atrioventricular valve.

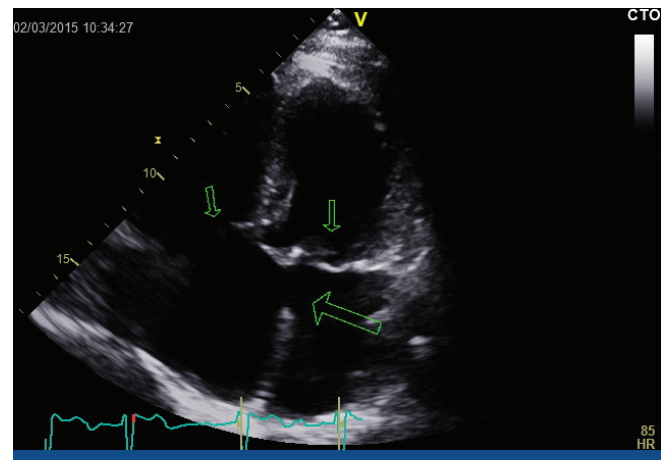

FIGURE 2. 4 chamber view - arrows pointing towards primum atrial septal defect and single atrioventricular valve/two separate valve orifices. 
AV canal defect and usually has both large primum atrial and inlet ventricular septal defects. Due to the natural division of the common AV valve into left and right AV valve components by the tongue of tissue, surgical division is not required.

Conclusion: Recent advances in echocardiography make it the first-line modality to diagnose AV canal defects; 3D transesophageal echocardiography is often used to determine additional anatomical and functional factors that impact surgical management.

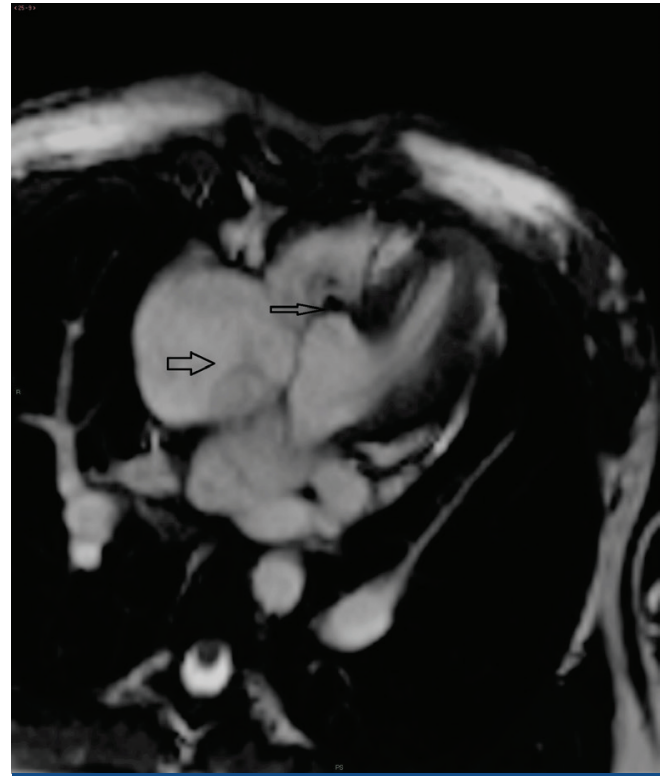

FIGURE 3. Cardiac magnetic resonance imaging showing interatrial aneurysm with primum atrial septal defect (big arrow) and large ventricular septal defects partially obstructed with septal tricuspid valve leaflet (narrow arrow).

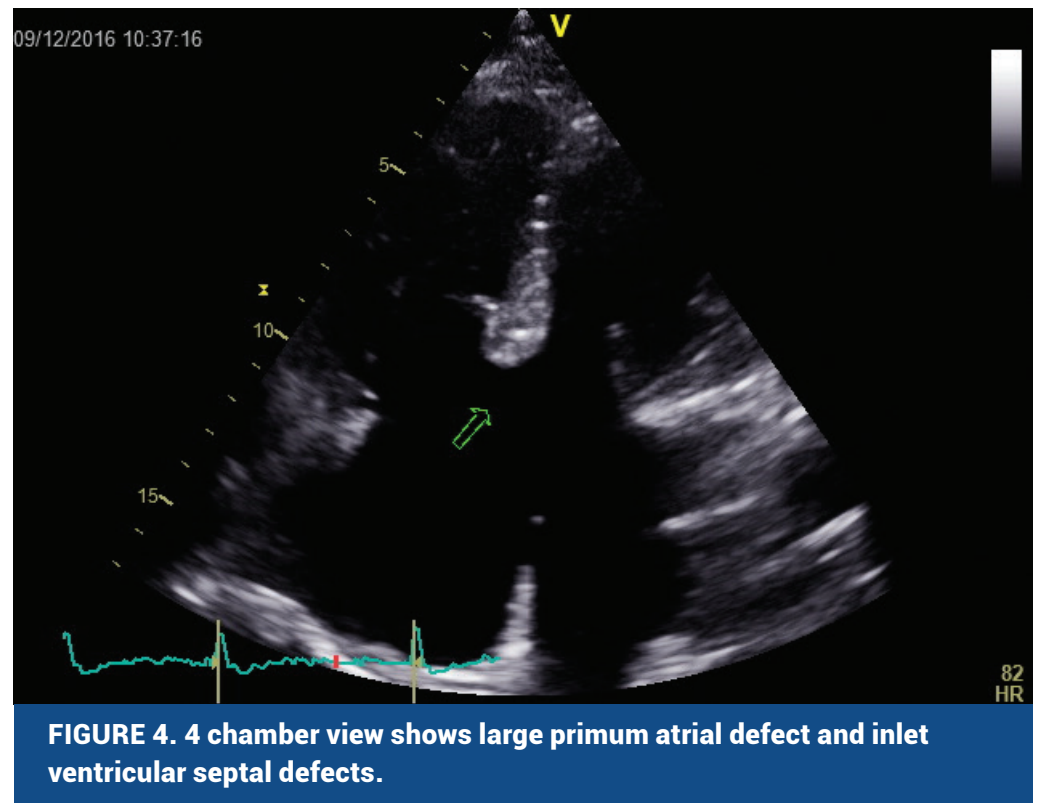

FIGURE 4. 4 chamber view shows large primum atrial defect and inlet ventricular septal defects.

1. Rastelli G, Kirklin JW, Titus JL. Anatomic observations on complete form of persistent common atrioventricular canal with special reference to atrioventricular valves. Mayo Clin Proc. 1966 May:41(5):296-308. https://www.ncbi.nlm.nih.gov/pubmed/5932615

2. Piccoli GP, Wilkinson JL, Macartney FJ, Gerlis LM, Anderson RH. Morphology and classification of complete atrioventricular defects. Br Heart J. 1979 Dec;42(6):633-9. https://www.ncbi.nlm.nih.gov/pubmed/534580

3. Del Pasqua A, Sanders SP, de Zorzi A, Toscano A, lacobelli R, Pierli C, et al. Impact of three-dimensional echocardiography in complex congenital heart defect cases: the surgical view. Pediatr Cardiol. 2009 Apr;30(3):293-300. https://doi.org/10.1007/s00246-008-9348-3

4. Catherine M. Otto. Textbook of Clinical Echocardiography. 5th ed. Elsevier | Saunders; 2013. 